\title{
Myasthenia gravis, Hashimoto's disease and pernicious anaemia
}

\author{
J. H. J. DURSTON* \\ M.A., M.B., M.R.C.P. \\ The West End Hospital for Neurology and Neurosurgery, London, W.1
}

THE ASSOCIATION of myasthenia gravis with Hashimoto's disease and pernicious anaemia was described in a patient by Singer \& Sahay (1966). Another patient with myasthenia gravis and pernicious anaemia who showed post-mortem evidence of Hashimoto's disease was reported by Simpson(1964). A further case history in which the patient had overt manifestations of these three conditions is described here.

\section{Case report}

Mrs F.G., a 48-year-old housewife, presented in 1960 with 1 year's history of intermittent diplopia and ptosis relieved by rest. Her symptoms and signs were abolished temporarily by intravenous edrophonium and were then controlled by oral prostigmine and pyridostigmine. There was no family history of myasthenia, pernicious anaemia or endocrine disorder.

The initial investigations showed a hypochromic anaemia (Hb 11.9 g/100 ml). The white cell count was normal and ESR $15 \mathrm{~mm} / \mathrm{hr}$ (Westergren). Chest radiographs were normal.

In 1961, her symptoms worsened and examination showed bilateral ptosis with paresis of the right superior oblique and of the left lateral rectus, superior oblique and inferior oblique muscles. There was still a hypochromic anaemia (Hb $10 \mathrm{~g} / 100 \mathrm{ml})$. The ESR had risen to $28 \mathrm{~mm} / \mathrm{hr}$. Clinical improvement was achieved by increasing the dose of anticholinesterases.

By 1963 she had again deteriorated and complained of dyspnoea on effort and tiredness. Again ptosis was seen and all external ocular movements were impaired in both eyes. Her thyroid gland was diffusely enlarged, her skin dry and her eyelids puffy.

Investigations showed the hypochromic anaemia was still present $(\mathrm{Hb} 10 \mathrm{~g} / 100 \mathrm{ml})$. The ESR had remained at $28 \mathrm{~mm} / \mathrm{hr}$ and the serum electrophoretic pattern was normal. The chest radiograph showed that her heart had increased in size compared with the film of 1960 and the aortic arch had dilated. Tomography of the mediastinum was normal. The

* Present address: Institute of Neurology, Queen Square, London, W.C.1. serum protein-bound iodine was low $(3.6 \mu \mathrm{g} / 100 \mathrm{ml})$ and the cholesterol elevated $(564 \mathrm{mg} / 100 \mathrm{ml})$. The thyroid antigen complement fixation test was positive $(1: 16)$ and the thyroglobulin tanned red cell test also positive $(1: 250)$.

Treatment was started with oral L-thyroxine sodium and her clinical condition improved.

The patient was reassessed in 1967 following the development of myasthenic weakness in all her limbs and pitting oedema of her ankles. Vibration sensation was markedly diminished over both medial malleoli.

An ECG was normal and no change was seen in chest radiographs or tomograms of the mediastinum. Although the haemoglobin concentration was $12.2 \mathrm{~g} / 100 \mathrm{ml}$ and the white cell count normal, the blood film was macrocytic and the bone marrow megaloblastic. The ESR was $30 \mathrm{~mm} / \mathrm{hr}$ and serum electrophoresis showed increased $\alpha_{2}, \beta-$ and $\gamma-$ globulins. Gastric juice analysis after maximal histamine stimulation showed complete achlorhydria and the serum vitamin $B_{12}$ was low $(131 \mu \mathrm{g} / \mathrm{ml})$. The serum cholesterol was now normal $(180 \mathrm{mg} / 100 \mathrm{ml})$.

The results of serum autoantibody studies done in May 1967 were as follows :

\section{Thyroid antibodies}

Thyroglobulin tanned red cell agglutination titre $=1: 160$.

Colloid antibody immunofluorescence, strongly positive. tive.

Cytoplasmic antibody immunofluorescence, posi-

Cytoplasmic antibody complement fixation titre $=1: 8$.

\section{Gastric antibodies}

Parietal cell antibody immunofluorescence, strongly positive.

Parietal cell antibody complement fixation titre $=0$.

Gastric intrinsic factor antibody, positive.

\section{Muscle antibodies}

Skeletal, positive.

Cardiac, positive.

Smooth, negative. 


\section{Non-organ-specific antibodies}

Antinuclear factor, negative.

Mitochondrial immunofluorescence, negative.

Mitochondrial complement fixation titre, negative.

By August 1968 the thyroglobulin tanned red cell agglutination titre had risen to $1: 640$, the cytoplasmic immunofluorescence test had become strongly positive and the cytoplasmic complement fixation titre had risen to $1: 32$. In 1968 no antibodies to skeletal or cardiac muscle were detected but antibodies to pancreatic and suprarenal tissue were found. Latex fixation and direct Coombs' tests were negative.

Treatment with intramuscular cyanocobalamin was started and there was symptomatic improvement although there was no marked anaemia when vitamin $\mathrm{B}_{12}$ deficiency was diagnosed. By 1968 the haemoglobin concentration was $12 \cdot 2 \mathrm{~g} / 100 \mathrm{ml}$ and the blood film normal. The myasthenic symptoms, however, have remained difficult to control.

\section{Comment}

The association of various clinical syndromes with autoimmune phenomena has been frequently recorded. Evidence of thyroid dysfunction and the finding of thyroid antibodies have been described in patients with myasthenia gravis (Simpson, 1960; Adner et al., 1964; Sahay, Blendis \& Greene, 1965). The finding of gastric antibodies or pernicious anaemia in patients with myasthenia gravis and the association of pernicious anaemia or defective vitamin $\mathbf{B}_{\mathbf{1 2}}$ absorption with Hashimoto's disease and thyroid antibodies have all been reported (Simpson, 1960, 1964; Downes, Greenwood \& Wray, 1966; Tudhope \& Wilson, 1960, 1962; Williams \& Doniach, 1962; Doniach, Roitt \& Taylor, 1963; Ardeman et al., 1966). Autoimmune phenomena have also been invoked in certain cases of Addison's disease and diabetes mellitus (Anderson et al., 1957; Blizzard et al., 1962; Turner \& Bloom, 1968).

Myasthenia gravis, hypothyroidism, hypoadrenalism, diabetes mellitus and pernicious anaemia may all present as muscular weakness. It is suggested, therefore, that full antibody testing should be performed as part of the initial investigation of any of these conditions in anticipation of the development of related syndromes. Weakness may also be caused by overdosage of anti-cholinesterases or thyroxine, thus increasing the factors which have had to be considered in the management of the patient described.

The association of autoimmune phenomena with myasthenia gravis supports the hypothesis of Simpson (1965) that this condition may be itself due to the development of antibodies to motor end-plate protein.

\section{Acknowledgments}

I thank Dr E. A. Nieman for helpful criticism and Dr D. Doniach for performing the antibody studies.

\section{References}

Adner, M.M., Sherman, J.D., Ise, C., Schwab, R.S. \& DAMESheK, W. (1964) An immunologic survey of fortyeight patients with myasthenia gravis. New Engl. J. Med. $271,1327$.

Anderson J.R., Goudie, R.B., Gray, K.G. \& Timbury, G.C. (1957) Auto-antibodies in Addison's disease. Lancet, i, 1123 .

Ardeman, S., Chanarin, I., Krafchik, B.R. \& Singer, W. (1966) Addisonian pernicious anaemia and intrinsic factor antibodies in thyroid disorders. Quart. J. Med. 139, 421.

Blizzard, R.M., Chandler, R.W., Kyle, M.A. \& Hung, W. (1962) Adrenal antibodies in Addison's disease. Lancet, ii, 901.

Doniach, D., RoitT, I.M. \& TAyloR, K.B. (1963) Autoimmune phenomena in pernicious anaemia. Brit. med. J. $1,1374$.

Downes, J.M., Greenwood, B.M. \& Wray, S.H. (1966) Auto-immune aspects of myasthenia gravis. Quart. J. Med. 35, 85.

Sahay, B.M., Blendis, L.M. \& Greene, R. (1965) Relation between myasthenia gravis and thyroid disease. Brit. med. J. 1, 762.

Singer, W. \& SAHAY, B.M. (1966) Myasthenia gravis, Hashimoto's thyroiditis and pernicious anaemia. Brit. med. J. $1,904$.

Simpson, J.A. (1960) Myasthenia gravis: a new hypothesis. Scot. med. J. 5, 419.

SimpSON, J.A. (1964) Immunological disturbances in myasthenia gravis with a report of Hashimoto's disease developing after thymectomy. J. Neurol. Neurosurg. Psychiat. 27, 485.

SIMPSON, J.A. (1965) Biochemical aspects of neurological disorders, 2nd series (Ed. by M. Kremer and J. N. Cumings), p. 53. Blackwell Scientific Publications, Oxford.

Tudhope, G.R. \& Wilson, G.M. (1960) Anaemia in hypothyroidism. Quart. J. Med. 29, 513.

TuDHOPE, G.R. \& Wilson, G.M. (1962) Deficiency of vitamin $B_{12}$ in hypothyroidism. Lancet, $\mathbf{i}, 703$.

TURner, R.C. \& Bloom, A. (1968) Diabetes mellitus, Addison's disease and pernicious anaemia. Postgrad. med. J. 44, 555.

Williams, E.D. \& Doniach, I. (1962) The postmortem incidence of focal thyroiditis. J.Path. Bact. 83, 255. 